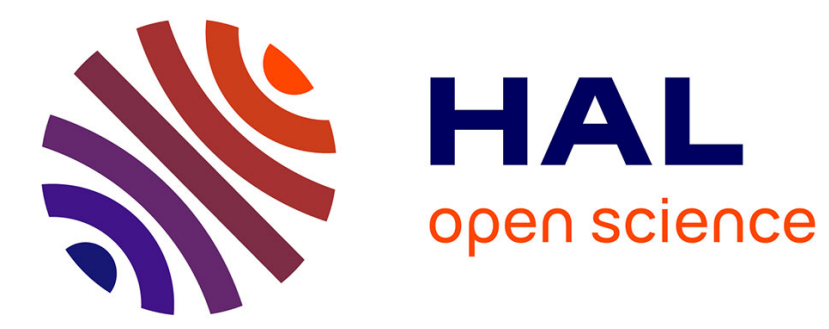

\title{
GLASS TRANSITION AS A FUNCTION OF COOLING RATE
}

\author{
S. Rekhson, G. Scherer
}

\section{To cite this version:}

S. Rekhson, G. Scherer. GLASS TRANSITION AS A FUNCTION OF COOLING RATE. Journal de Physique Colloques, 1982, 43 (C9), pp.C9-427-C9-430. 10.1051/jphyscol:1982983 . jpa-00222512

\section{HAL Id: jpa-00222512 https://hal.science/jpa-00222512}

Submitted on 1 Jan 1982

HAL is a multi-disciplinary open access archive for the deposit and dissemination of scientific research documents, whether they are published or not. The documents may come from teaching and research institutions in France or abroad, or from public or private research centers.
L'archive ouverte pluridisciplinaire HAL, est destinée au dépôt et à la diffusion de documents scientifiques de niveau recherche, publiés ou non, émanant des établissements d'enseignement et de recherche français ou étrangers, des laboratoires publics ou privés. 
JOURNAL DE PHYSIQUE

Colzoque c9, supplément au $n^{\circ} 12$, Tome 43, décembre 1982

page $\mathrm{C} 9-427$

\title{
GLASS TRANSITION AS A FUNCTION OF COOLING RATE
}

\author{
S.M. Rekhson and G.W. Scherer* \\ General EZectric Co., NeZa Park, Cleveland,OH 44112, U.S.A. \\ *Coming GLass Works, Coming, NY 14830, U.S.A.
}

Résumé. - On décrit une méthode permettant le calcul des relaxations de structure dans des verres refroidis très rapidement. L'obstacle majeur dans le modèle

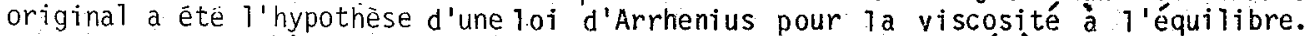
Ic $i$ on emploie l'équation de Macedo-litovitz pour la viscosité à l'équilibre. on nontre que la zone de transition vitreuse est déplacée vers les hautes températures et s'ślargit quand on augmente 1 a vitesse de refroidissement. Les verres à $T_{g}$ élevé e.g. Sion ont une zone de transition vitreuse plus large que les verres de $T_{g}$ plus bas mais avec une énergie d'activation similaire.

Abstract. - The method is described for calculating structural relaxation in glasses cooled very rapidly. The major obstacle for the calculation was the assumption in the original model of Arrhenius behavior for the equilibrium viscosity. In this paper the Macedo-Litovitz' hybrid equation is used for the equilibrium viscosity. The glass transition region is shown to shift to higher teriperatures and to broaden as the cooling rate increases. Glasses with higher $\mathrm{T}_{\mathrm{g}}$ e.g. $\mathrm{SiO}_{2}$ are shown to have broader glass transition region than glasses with lower $T_{g}$ but similar activation energy.

Perpetual intensifying and shortening of the annealing cycles in glass manufacturing, the advent of fiber optics, metallic glasses and splat cooling technique raise the question how the glass transition occurs at cooling rates, $q$, $3,5,7$ orders of magnitude higher than the one conventionally used in the 1 aboratory. It is well known that the glass transition interval will shift to higher temperatures, or lower viscosities as the cooling rate increases. That formulates the problem.

In the structural relaxation model by Marayanaswamy [1] the viscosity is assumed to be related to the temperature by Arrhenius equation. According to Mazurin, Startsev and Potseluyeva [2] this is a good approximation for the viscosity below the glass transition temperature, To. For equilibrium viscosity it holds only for a narrou temperature interval. Fulcher-Vogel- Tamman or MLF equations give better results for the equilibrium viscosity but fail to predict Arrhenius dependence below $\mathrm{T}_{\mathrm{g}}$. Therefore we have chosen to work with the Macedo and Litovitz [3] hybrid equation, incorporating the elements of both free volume and activated flow theory.

The equation is:

$$
n=n_{0} \exp \left(\frac{r_{c}}{v_{f}}+\frac{Q}{T}\right)
$$

where $\eta=v i s c o s i t y, \eta_{0}, \gamma$ and $Q$ are constants $v_{C}=$ core or occupied volume of atoms (exclusive of interatomic volume), and $v_{f}=$ free volume $=v-v_{c}$, where $v=$ total volume. 
In Eq. (1), $v_{f}$ is inheritantly poorly defined. An important feature of $v_{f}$, i.e. freezing in the glass transition region during cooling has not been reflected in the mathematical formation. He have derived and will publish the derivation elsewhere, the following equation for $v_{f} / v_{c}$ in Eq. (1):

$$
v_{f} / v_{c} \simeq \int_{T_{1}}^{T_{f}} a_{s} d T^{\prime}
$$

where $\alpha_{S}=\alpha_{\ell}-\alpha_{g}$ is the structural themal expansion coefficient defined as the difference between the themal expansion coefficients of 1 iquid and glass. $T_{1}$ is the temperature at which the volume of the liquid equals the core volume $\left(v_{f}=0\right)$.

Eq. (2) clearly shows that $v_{f}$ freezes when $T_{f}=$ const. The higher the 1 initing $T_{f}$, i.e. the higher the cooling rate, the larger is the free volume frozen in.

For some glasses $\alpha_{s}$ can be assumed to be constant and Eq. (1) becones

$$
n=\eta_{b} \exp \left[\frac{\gamma}{\alpha_{s}\left(T_{f}-T_{1}\right)}+\frac{Q}{T}\right]
$$

When $T_{f}=T$ the first tern in the brackets is in form $B /\left(T-T_{0}\right)$ of Fulcher equation. When $T_{f}=$ const. this term is constant and the equation is Arrhenius.

For other glasses $\alpha_{S}=\alpha_{0}+\alpha_{1} T$ and Eq. (1) becomes

$$
n=n_{0} \exp \left[\frac{\gamma / \alpha_{0}}{\left(T_{f}-T_{1}\right)\left(1+\frac{\alpha_{1}\left(T_{f}+T_{1}\right)}{2 \alpha_{0}}\right)}+\frac{0}{T}\right]
$$

Eq. (4) has been used for calculation of the glass transition in the NBS 710 glass cooled at a rate of $10^{-2}, 10^{0}, 10^{4}, 70^{6} \mathrm{~K} / \mathrm{min}$. The input parameters included $\gamma / \alpha_{0}=2.65 \cdot 10^{4} \mathrm{~K}, Q=3.59 \cdot 10^{4} \mathrm{~K}, \eta_{0}=3.69 \cdot 10^{53}$ $\mathrm{Pa} \cdot \mathrm{s}, \quad \mathrm{T}_{1}=253.8 \mathrm{~K}, \alpha_{1} / \alpha_{0}=-10.4 \cdot 10^{-4} \mathrm{~K}-1$. For the calculation of $T_{f}$ we used the model developed by Narayanaswary [1]. The results of the calculations are given in Fig. 1. The equilibrium viscosity of ABS 710 was carefully measured by Napolitano and coworkers [4]. The standard deviation of the fit of their data to Eq. (4) given above is .042 in terms of $70 g \mathrm{n}$. The quaitity of the fit is better than that to Fulcher equation for which the standard deviation is .06 [4]. When $T_{f}=$ const. Eq. (4) predicts Arrhenius behavior with $Q=3.59 \cdot 10^{4} \mathrm{~K}$ experimentally found by Mazurin and coworkers [2]. The glass transition is not only shifted to higher temperatures but al so becomes broader. It is shown better in Fig. 2. The lower and the upper temperatures of the glass transition region, $i . e$. the temperatures $T_{L}$ and $T_{U}$, are defined in this wark as the temperatures at which $\frac{\mathrm{dT}_{f}}{\mathrm{dT}}=.01$ and .99 respectively.

How can we rationalize the broadening of the glass transition as the cooling rate increases? The fundamental feature of glass transition is that the structural relaxation time, $\tau$, increases nuch faster than the real time, $t$. At $T=T_{U}, \quad \mho \ll t$ and the structure easily follows the change in the temperature. At $T=T_{L}, \eta_{l} \gg t$ and the structure is frozen. Our calculation shows that $\eta_{\mathrm{L}} / \mathrm{T}_{\mathrm{U}} \simeq 4 \cdot 10^{5}$ regardiess of the cooling rate. The structural relaxation time has the sane tenperature dependence as the viscosity. Therefore Fig. 1 can be used to explain the observed broadening. At 


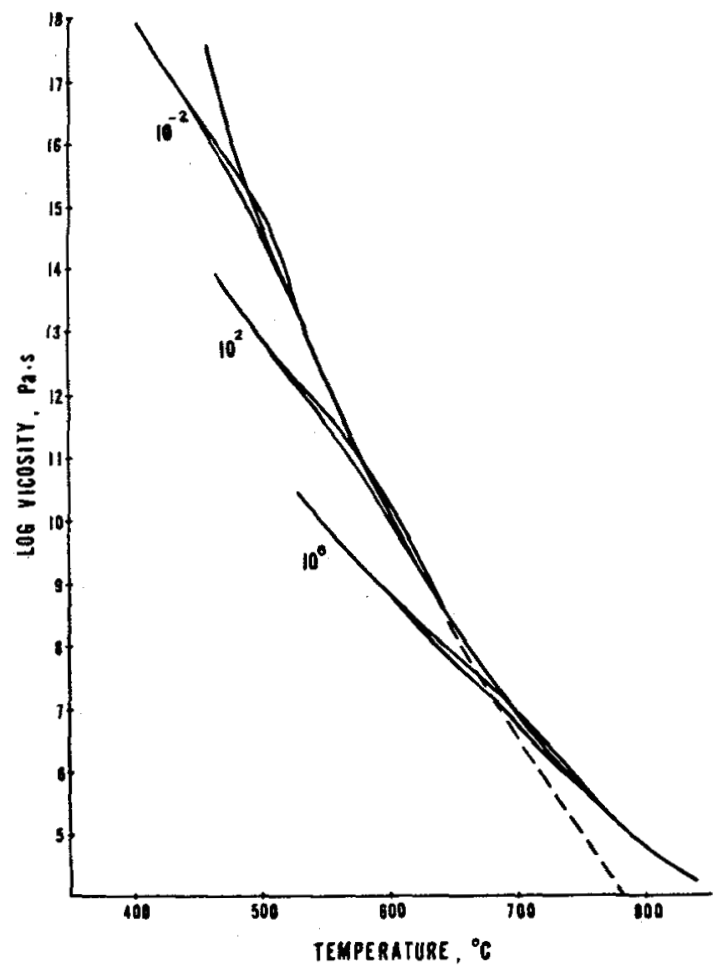

Fig. 1. Viscosity of NBS 710 via hybrid equation; equilibrium viscosity and that for cooling and subsequent reheating with the rates given at the curves in $\mathrm{K} /$ min. Dashed line - Arrhenius approximation with the activation energy determined in the range of $10 \leq \log n \leq 13$.

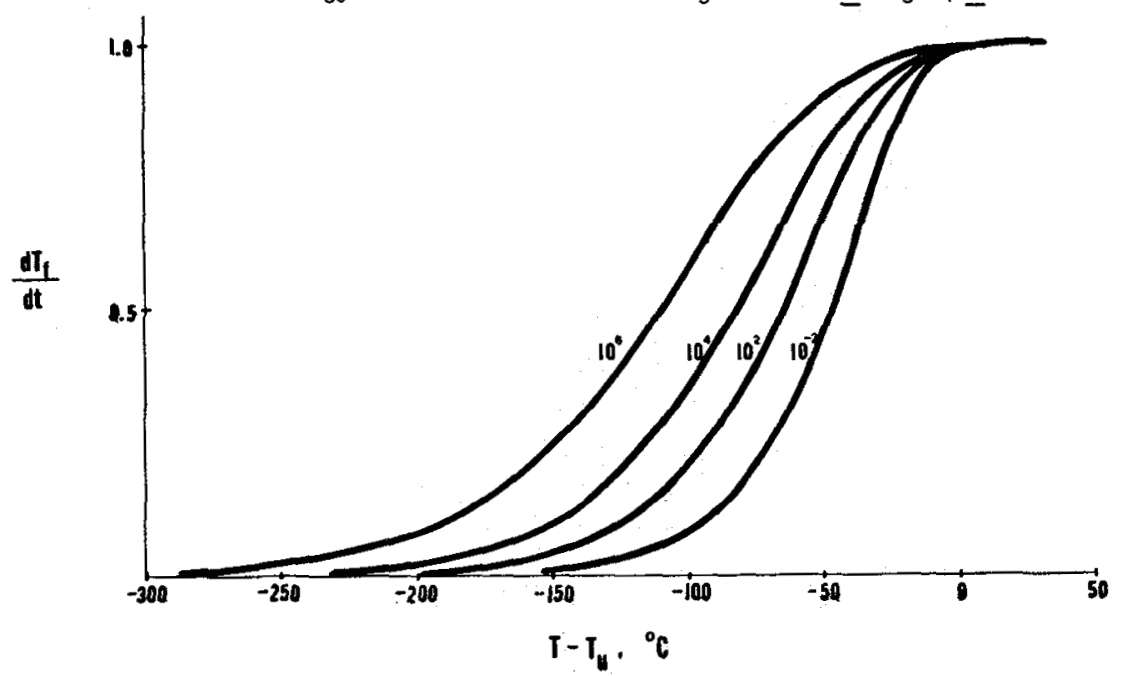

Fig. 2. Broadening of the glass transition region with increase in cooling rate (given at the curve in $\mathrm{K} / \mathrm{min}$ ). 
higher temperatures the terperature dependence of $\tau$ is shallower, therefore the liquid will travel a longer way on the temperature scale to accumnulate the 5 orders of increase in $\tau$ needed for the glassification.

That suggests however that the glasses which intrinsically have higher $\mathrm{Ig}$ will have broader glass transition interval than the glasses with the lower $\mathrm{T}_{\mathrm{g}}$ but the same activation energy. This is shown to be true in Fig. 3. We compare here a soda-lime-silicate glass $\left(\mathrm{Tg}_{\mathrm{g}}=530^{\circ} \mathrm{C}\right)$ and $50_{2}\left(\mathrm{~T}_{\mathrm{g}}=1098^{\circ} \mathrm{C}\right)$. Equations and parameters used for calculations are given in ref. [5].

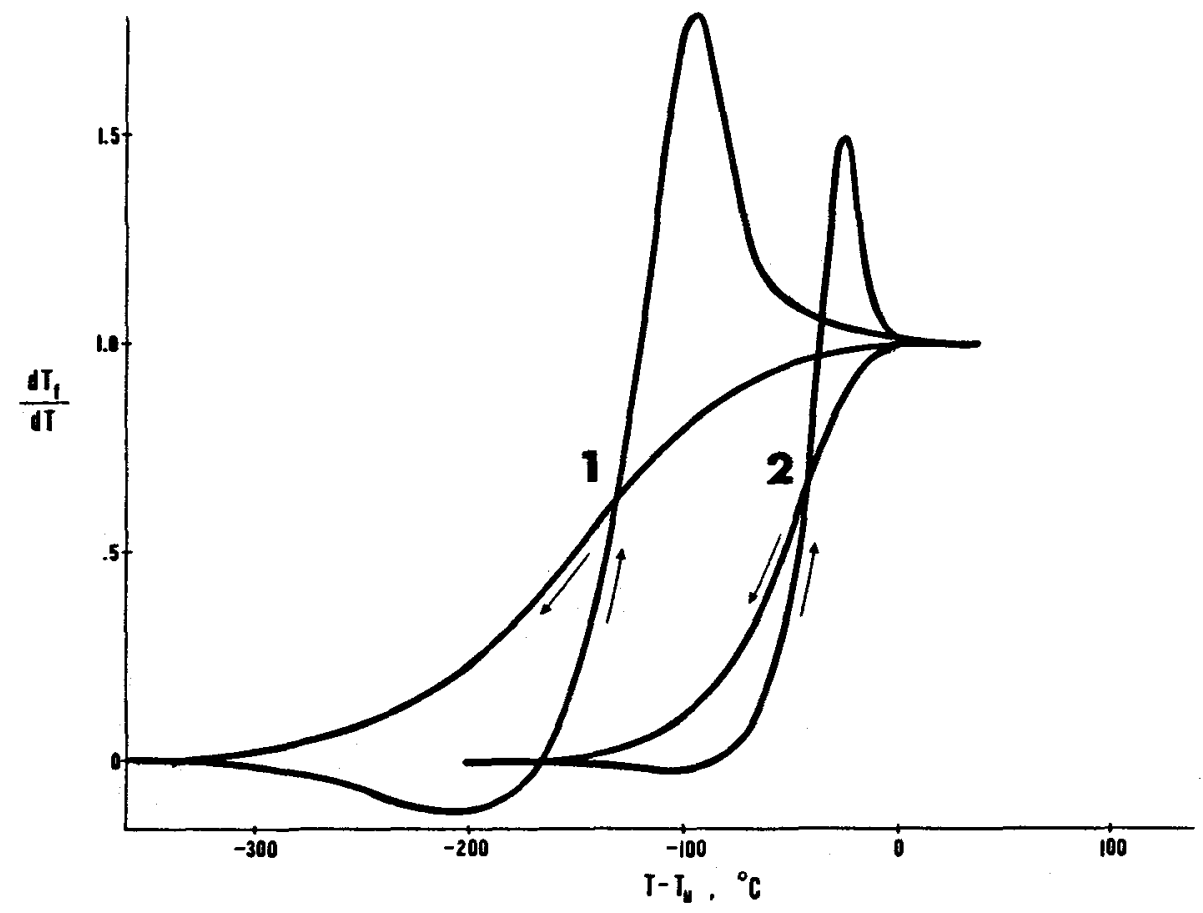

Fig. 3. Glass transition during cooling and reheating at a rate $3 \mathrm{k} / \mathrm{min}$ in $\mathrm{SiO}_{2}(1)$ and soda-1ime-silicate glass (2). $\mathrm{T}_{\mathrm{u}}=1253^{\circ} \mathrm{C}$ for $\mathrm{SiO}_{2}$ and $588^{\circ} \mathrm{C}$ for soda-lime-silicate glass.

\section{References}

1. narayanashamy,0. S., 1. An. Ceran. Soc. 54 (1974) 491.

2. MAZURIN, 0. V., STARTSEV, YU. K., and POTSELUYEVA, L. N., Sov. J. G1 asS Phys. Chern. $5(1979)[1]$.

3. MACEDO, P. B. and LITOVITZ, T. A., J. Chen. Physics 42 (1965) 245.

4. HAPOLITANO, A., SIMMOHS, J. H., BLACKBURN, D.H., and CHIDESTER, R. E., J. of Research of NBS - A. Physics and Cheriistry 78A (1974) 323.

5. SCHERER, G. H. and REKHSON, S. M., J. Am. Ceran. SOC. 65 (1982) C94. 